\title{
How Setting Goals Enhances Learners' Self-Efficacy Beliefs in Listening Comprehension
}

\section{Cómo el diseño de metas promueve las creencias de auto-eficacia en la comprensión auditiva*}

Liliana Ballesteros Muñoz

charito72@yahoo.com

IED Ciudadela Educativa de Bosa, Colombia

Silvana Tutistar Jojoa

mjct1998@hotmail.com

IED Miguel de Cervantes Saavedra, Colombia

This article outlines a study that explores the relationship between SMART goal setting (Specific, Measurable, Attainable, Relevant, and Time-based) and learning English in Colombia concerning a foreign language learners' self-efficacy beliefs in listening. The participants were seventh and ninth grade students of two schools in Bogotá, Colombia. The results revealed that self-efficacy was highly positive when related to goal setting as students were able to set SMART goals to improve their listening comprehension and learners showed improvement in self-efficacy beliefs and felt more motivated while completing listening tasks related to songs. Furthermore this study shows that goal setting training can be incorporated successfully into the English as a foreign language classroom.

Key words: Goal setting, listening, metacognition, self-efficacy

Este artículo expone un estudio que explora la relación entre el diseño de metas (específicas, medibles, alcanzables, relevantes, con límite de tiempo: SMART goals) y las creencias de autoeficacia en comprensión oral de estudiantes de inglés como lengua extranjera en Colombia. Los participantes fueron estudiantes de grado séptimo y noveno de dos colegios en Bogotá. Los resultados revelaron que la autoeficacia está altamente relacionada con el diseño de metas, ya que los estudiantes fueron capaces de establecer metas $S M A R T$ para mejorar su comprensión auditiva. También reportaron una mejora en sus creencias de autoeficacia al realizar actividades de escucha relacionadas con canciones y se sintieron también más motivados. Además, este estudio muestra que la instrucción sobre diseño de metas pude ser incorporado exitosamente en clases de inglés como lengua extranjera.

Palabras clave: autoeficacia, comprensión auditiva, diseño de metas, metacognición

* Received: October 30, 2013. Accepted: February 3, 2014. 
How Setting Goals Enhances Learners' Self-Efficacy Beliefs in Listening Comprehension

\section{Introduction}

Since listening is one of the most important skills when learning a language, it is essential to look for strategies to implement in the classroom that will allow students to overcome difficulties associated with a listening task. Providing students with strategies instruction has proven to be a useful tool to enhance listening comprehension (Vandergrift, 1999; Rubin, 1994). By engaging students in the use of strategies, the present study draws from goal setting — a planning metacognitive strategy — and self-efficacy — a motivational measure-as two outstanding theories which underlie this investigation.

Locke and Latham (1990) provided a goal-setting theory of motivation which has been relevant to researchers involved in this field. This theory emphasizes the important relationship between goals and performance. They found there was a close relationship between a learner's performance of a task and the difficulty and specificity of a goal, that is, when a learner sets hard and specific goals there is more motivation to achieve them.

Bandura (1997) stated that self-efficacy determined how people feel, think, motivate, and behave. A person with strong self-efficacy beliefs sets challenging goals and maintains a commitment to them. This author also provided evidence about the considerable influence of self-efficacy beliefs in learning processes, since they represent a cognitive mechanism that mediates between knowledge and action and determines the success of one's actions in the attainment of personal goals.

Consequently, the aim of this study is to determine the effect of SMART goal setting on learners' self-efficacy beliefs in listening. It also advocates for an innovative integration of setting SMART goals into the school curriculum and classroom activities.

\section{Going Deeper Into SMART Goal Setting and Self-Efficacy}

\section{Goal Setting}

"Metacognition combines a variety of thinking and reflective processes. It can be divided into five elements: (1) preparing and planning for learning, (2) selecting and using learning strategies, (3) monitoring strategy use, (4) orchestrating various strategies, and (5) evaluating strategy use and learning" (Anderson, 2002, p. 2). Preparation and planning are important metacognitive skills that can improve students' learning; learners can reflect on the particular learning goals they might set for a task and measure their progress based on their goals.

Locke and Latham (1990) have proposed a partial model of task motivation, the basic premise being that an individual's conscious intentions or goals are the primary determinants of task motivation. Further, their theory suggests that hard goals result in greater effort than 
easy goals and that specific goals result in higher effort than no goals or more generalized goals.

According to Locke and Latham (1990), goal setting and performance have a close relationship; a goal should be measurable as to what the person has to do in order to achieve that specific goal. And ambiguous or too easy goals may not produce the individual's desired level of performance.

Goal setting theory postulates that goals affect performance through four mechanisms: direction, effort, persistence, and strategy development (Locke \& Latham, 2002). Direction refers to how learners focus their attention and effort toward goal relevant activities and avoid irrelevant activities. This happens in both aspects: cognitive and behavioral. Effort is related to high goals since they lead to greater resolution even more than low goals. Since different goals may require different amounts of effort, effort is mobilized simultaneously in direct proportion to the perceived requirements of the task. Persistence is a directed effort extended over time; so, it is a combination of the previous mechanisms: direction and effort. Finally, Early and Perry (as cited in Locke \& Latham, 2002, p. 707) assert "when people are trained in the proper strategies, those given specific high-performance goals are more likely to use those strategies than people given other types of goals; hence, their performance improves."

Locke and Latham (2002) outline five characteristics of successful goal setting:

1. Clarity: Clear goals are measurable and unambiguous. When a goal is clear and specific, with a definite time set for completion, there is less misunderstanding about what behaviors will be rewarded.

2. Challenge: One of the most important characteristics of goals is the level of challenge. People are often motivated by achievement, and they will judge a goal based on the level of significance of the anticipated accomplishment.

3. Commitment: Goal commitment and difficulty often work together. The harder the goal, the more commitment is required.

4. Feedback: In addition to selecting the right type of goal, an effective goal program must also include teacher and peer feedback. It provides opportunities to clarify expectations, adjust goal difficulty, and gain recognition.

5. Task Complexity: People who work in complicated and demanding roles probably have a high level of motivation already. (p. 715)

According to Locke (as cited in Griffee \& Templin, 1997), task complexity is another important characteristic which can moderate the effects of goals. If the task becomes too overwhelming for learners, there are chances that they can feel a little demoralized. When this happens, learners may feel frustrated and may not want to attain the goal. If difficult goals appear, there is a need to set several smaller goals. So, it promotes pupils' progress feedback. 


\section{Self-Efficacy}

Bandura (1997) defined self-efficacy as "beliefs in one's capabilities to organize and execute the courses of action required to produce given attainments" (p. 3). The concept of self-efficacy arose from Bandura's social cognitive theory in 1977. According to Bandura's theory, human behavior, environment, and personal factors interact and influence each other through the process of reciprocal determinism. For example, a person's self-efficacy (personal factor) can be an indicator of how a person self-regulates their performance (behavior), and their performance can affect their future self-efficacy beliefs in turn (Bandura, 1997).

The most important characteristic of self-efficacy is that it is task and situation specific (Bandura, 1997). That is, self-efficacy beliefs may differ according to the task a person is responsible for and the situation in which they need to perform. Moreover, Bandura pointed out that self-efficacy beliefs differ in level, generality, and strength. The level of self-efficacy depends on the difficulty of the task; generality relates to the transferability of self-efficacy beliefs across activities; and strength means that having a stronger sense of self-efficacy beliefs causes an increase in perseverance when faced with difficulties and hence a greater possibility of being successful.

Bandura (1997) provided evidence about the great influence of self-efficacy beliefs in learning processes, since they represent a cognitive mechanism that mediates between knowledge and action and can determine the success of one's actions in the attainment of personal goals. Self-efficacy beliefs generate changes in students' performance, processes of self-regulated learning, and students' academic achievement through four major processes that include cognitive, motivational, affective, and selective processes.

\section{Research Design}

This study follows a mixed method or hybrid design that utilizes qualitative and quantitative data collection and analysis procedure. Dörnyei (as cited in Nunan \& Bailey, 2009 , p. 439) states that a mixed method study is one that "involves the collection or analysis of both qualitative and quantitative data in a single study with some attempts to integrate two approaches at one or more stages of the research process." This method offers the opportunity to move from theory to practice, and find practical solutions to issues related to academic contexts. This research investigates the effects of SMART goal setting on self-efficacy in listening activities with seventh and ninth grade students in two public schools in Bogota, Colombia. It aims to understand and interpret how setting goals enhances learners' self-efficacy beliefs in listening comprehension. 


\section{Pedagogical Intervention}

The pedagogical intervention consisted of one introductory lesson, 110 minutes, on self-directed learning to introduce this subject. This lesson was also piloted with a group of students who were at the same level as the participants of the study; and ten weekly lessons, 110 minutes each one, on SMART goal setting using songs as a tool to enhance listening comprehension. Each lesson was specially designed bearing in mind a SMART goal feature (Specific, Measurable, Attainable, Relevant, Time-based). Students were asked to plan, monitor, and assess their goals according to the scaffolding provided by the tutor. Correspondingly, each lesson was focused on a specific listening strategy, associating, using imagery, using key words, representing sounds, scanning, and skimming. After each lesson, pupils were instructed to reflect on the lessons by answering questions regarding setting goals and the obstacles found along the process in journals they were asked to write.

\section{Instructional Design}

To accomplish the aim of the research, the instructional design was based on the Cognitive Academic Language Learning Approach model (CALLA) developed by Chamot and O'Malley (1994). This model integrates teaching academic content, development of language skills and explicit training in using learning strategies for academic tasks. The model promotes language awareness, cooperative learning, enhancing intrinsic motivation and making learners more independent and self-regulated.

The instructional design consisted of the elaboration of an action plan which was developed in three stages: Pre-Stage, While-Stage, and Post-Stage.

\section{Pre-Stage}

The population was selected, the main problems were identified, lesson plans and materials were designed as well as the strategies to be used in each one. During this stage an introductory lesson was presented and self-efficacy and goal setting pre-tests were given (see Appendix 1).

\section{While-Stage}

Ten lesson plans were delivered to students and journals were kept by learners and practitioners of the research (see Appendix 2 for a sample lesson plan).

\section{Post-Stage}

Self-efficacy and goal setting post-tests (see Appendix 3) were applied to pupils after the intervention. 
All this process was developed in class corresponding to the academic schedule in each school.

\section{Participants}

This group consisted of 40 secondary students in two public schools: Miguel de Cervantes Saavedra IED and Ciudadela Educativa de Bosa in Bogota, Colombia. Their ages ranged from 11 to 15 years.

It is worth mentioning that none of the students had any prior specific training related to this self-regulated learning and they had not participated in other investigations before this one.

\section{Results and Data Analysis}

The results of this study showed that both seventh and ninth graders had an outstanding progress in setting SMART goals. In fact, the pre-test showed that none of the students were able to set SMART goals properly, while the post-test indicated that a growing number of students, $35 \%$ in seventh grade and 52\% in ninth grade, could set SMART goals suitably. To some extent, ninth graders showed a better performance in the design of SMART goals; conversely, younger pupils had a lower performance due to their age and degree of maturity or knowledge base.

Comparing the results of self-efficacy pre- and post-tests and goal setting pre- and post-tests, it is noticeable that there was a positive relation between improvement in setting SMART goals and changes in learners' self-efficacy beliefs in listening. For instance, in seventh grade students, the areas of biggest improvement were the ones related to feelings, association of the words they had heard before, and giving their opinion about what they heard. Whereas in ninth grade, students' perceptions were highly notable in making predictions about the contents of the song based on the title, identifying the type of the song, comparing new songs with the ones they had heard before, and guessing new words. Both groups made progress translating key words, planning strategies to work on the listening tasks, and thinking of a solution when having problems; nevertheless, the percentage of ninth graders was significantly higher in relation to finding strategies to solve problems.

In the journals (see Appendix 4) students confirm that there is also a remarkable progress in learner's self-efficacy beliefs in listening. Students expressed their enthusiasm and changes in intrinsic motivation, since they were able to set their own goals and assess them at the end of the intervention. Students also expressed their improvement on solving problems, asserted they asked for clarification when needed, received support from their peers, or obtained scaffold from the tutor. 
In this class we learned how to set relevant goals, this is the first time I heard that word; the teacher explain us by means of a fable: "The City Mouse and the Country Mouse." In that way it was easier, even though many of us had to redesign the goal. After that, we worked on the song: "Meet me Halfway," to find contractions. It was interesting because it is related to songs and their jargon, as the teacher said.

I guess that I achieved my goal because I was focused on the lyrics and the teacher gave us the chance of listening as many times as we want.

To conclude, we shared strategies into small groups, most of us wrote that the best option was to ask to the teacher, some other wrote that the most important thing was listening to the song several times or use the dictionary. The activity was interesting, every session we learn more.

(S14, Journal Entry, Lesson Plan 5) ${ }^{1}$

In sum, the results of the research confirm what previous studies about goal setting (Locke \& Latham, 1990) and self-efficacy (Bandura, 1997) found. Training students in setting SMART goals has a progressive effect on learners' self-efficacy beliefs affecting positively their performance in listening tasks. It was also confirmed that the use of songs is beneficial in providing students with rich and meaningful language.

\section{Conclusions and Pedagogical Implications}

The work done in this study fulfilled the objectives proposed, reflecting on the fact that setting SMART goals affects self-efficacy beliefs and performance in listening tasks in a positive manner.

In conclusion, as Koda-Dallow and Hobbs (2005) and Jackson (1999) assert, learners' self-efficacy (self-confidence) increases through goal setting. In the present study SMART goal setting also has a positive effect on self-efficacy in listening comprehension. It was slightly more effective for older learners (ninth graders) compared to younger ones (seventh graders). Both groups of students overwhelmingly experienced an improvement in their ability to plan and assess their goals. In addition, the majority of participants felt motivated to achieve their goals which contributed to improving learners' beliefs in listening comprehension. In a previous research conducted by Barca-Lozano, Almeida, Porto-Rioboo, Peralbo-Uzquiano, and Brenlla-Blanco (2012), researchers found that academic goals and the learning strategies as well as self-efficacy are indicators of and decisive factors for academic achievement.

Journals were very useful and effective to gain insights in the perceptions, feelings, attitudes, and thoughts of the participants.

1 The original journals were written in Spanish. 
This study also contributed to increases in self-directed learning, making students more responsible and autonomous of their own learning process. Besides, learners gained knowledge about how to learn, plan, and achieve outcomes. The tools provided by the research allow students to make their own decisions and transfer that knowledge into new, real situations such as setting goals for other subjects and their lives.

It is expected that the outcomes of this research will contribute to deepening our understanding in this area and provide us with some ideas as to how to use goal setting in other EFL lessons. The design of this pedagogical intervention could provide support on future research about the effectiveness of the use of SMART goal setting as a teaching strategy and an alternative learning tool.

Unlike most of the studies done in ESL settings with university students, the present study was developed in Colombia which differs from others, since it was carried out with secondary level learners in an EFL context and was specifically designed to enhance self-efficacy in listening by means of SMART goal setting, using songs as a pedagogical tool. Furthermore, this field has not been addressed at all in language learning in the Colombian context. In terms of the results, it can be said that learners who set goals and receive scaffolding and monitoring from tutors improve their language skills such as Skye (2000) affirms; moreover, goal setters have more motivation toward learning English; greater concentration on the tasks to be learned, and perform language skills more confidently with greater linguistic complexity. The results of this study made evident the relevance of integrating research into the curriculum, connecting self-directed learning and EFL teaching. Teachers should facilitate and prioritize the use of strategies that promote learners' autonomy and responsibility for their own learning processes. Goal setting would be a positive addition to the EFL classroom for developing learners' self-efficacy.

Considering that other fields of study can contribute to addressing issues in other areas of knowledge, it is important to point out that this research was supported by a psychological theory: the goal setting theory, which has not been approached in English language teaching in the Colombian context so far. In addition, this theory allowed planning the lessons and activities based on the main aspects stated by Locke and Latham (1990).

Students need to be provided with time to interact and apply the knowledge gained during the development of this research study and continue working in this field. ESL and EFL teachers must learn to properly set classroom goals and, more importantly, facilitate student goal setting to accomplish their language learning objectives. It is important to highlight that goals set by teachers should be concrete and achievable, as well as to bear in mind that learners need training in establishing long-and short-term goals since this type of instruction will make it possible to set personal goals in their future life (Graybeal, n.d.). 
Additionally, learner goal-setting may include the establishment of classroom, study and learning, educational, career, financial, personal, and community goals. By creating student-centered lessons, teachers provide ESL students with opportunities to articulate goals, determine steps to achieve goals, define timelines for reaching goals, and participate in goal-attainment activities. Therefore teachers need to develop and facilitate a variety of classroom goal-oriented activities. Goal-setting may be carried out in whole class, pair, and small group configurations. When individual students reach their set goals, teachers need to provide those students with opportunities to set and implement new goals.

Regarding the use of music while teaching English, according to Wood (as cited in Carmona, 2011) "it is a great way to create a friendly, comfortable atmosphere for students to learn. .. . The nature of the music changes the act of learning English to the act of experiencing English, which may allow students to focus on the core principles of the language in a manner unlike traditional grammar lessons or drills" (Potential, para. 1). The materials designed for the lessons included different listening strategies to work the songs such as discrimination of sounds and contractions; identification of synonyms, antonyms, and cognates; comparison of songs, and so forth. The songs used in the lessons are mainly pop songs, hence they are one of the most captivating and culturally rich resources that can be easily used in language classrooms. Songs become an excellent tool to develop students' listening abilities, as well as the development of many language elements such as vocabulary, sentence patterns, pronunciation, and rhythm.

\section{References}

Anderson, N. J. (2002, April). The role of metacognition in second language teaching and learning. ERIC Digest. Retrieved from http://www.cal.org/resources/digest/digest_pdfs/0110_ Anderson.pdf

Bandura, A. (1997). Self-efficacy: The exercise of control. New York, NY: Freeman.

Barca-Lozano, A., Almeida, L. S., Porto-Rioboo, A. M., Peralbo-Uzquiano, M., \& Brenlla-Blanco, J. C. (2012). Motivación escolar y rendimiento: impacto de metas académicas, de estrategias de aprendizaje y autoeficacia [Motivation and school performance: The impact of academic goals, learning strategies, and self-efficacy]. Anales de Psicología, 28(3), 848-859.

Carmona, H. (2011, June 14). English opens doors to future [Web log post]. Retrieved from http://hectorenglish123.blogspot.com/2011/06/importance-of-using-songs-while.html

Chamot, A. U., \& O'Malley, J. M. (1994). The CALLA Handbook: Implementing the cognitive academic language learning approach. White Plains, NY: Longman.

Graybeal, L. (n.d.). How to set goals for ESL (English as a second language) classes. ESL Teachers Board. Retrieved from http://www.eslteachersboard.com/cgi-bin/articles/index.pl?read= 5006 
Griffee, D. T., \& Templin, S. A. (1997). Goal setting affects task performance. In B. Visgatis (Ed.), Proceedings of the JALT 1997 International Conference on Language Teaching and Learning, (pp. 21-26). Retrieved from http://jalt-publications.org/archive/proceedings/previous/jalt97.pdf\#page=29

Jackson, S. F. (1999). Teaching short-term and long-term goal-setting to ESL students. North East, PA: The Pennsylvania Action Research Network.

Koda-Dallow, T., \& Hobbs, M. (2005). Personal goal-setting and autonomy in language learning. Proceedings of the Independent Learning Association Conference Inaugural, Auckland, New Zealand.

Locke, E. A, \& Latham, G. P. (1990). A theory of goal setting and task performance. Englewood Cliffs, NJ: Prentice-Hall.

Locke, E. A, \& Latham, G. P. (2002). Building a practically useful theory of goal setting and task motivation: A 35-year odyssey. American Psychologist, 57(9), 705-717. Retrieved from http:/ /www.owlnet.rice.edu/ antonvillado/courses/08c_psyc101002/Research\%20Report $\% 204 . p d f$

Nunan, D., \& Bailey, K. M. (2009). Exploring second language classroom research: A comprehensive guide. Canada: Heinle Cengage Learning.

Rubin, J. (1994). A review of second language listening comprehension research. Modern Language Journal, 78(2), 199-221. Retrieved from http://jan.ucc.nau.edu/ jgc/512/listening_rubin.pdf

Skye, J. (2000). A study of goal setting for language acquisition in the ESL classroom. The Korea TESOL Journal, 3(1), 77-86.

Vandergrift, L. (1999). Facilitating second language listening comprehension: Acquiring successful strategies. ELT Journal, 53(3). Retrieved from http://203.72.145.166/ELT/files/53-3-3.pdf

\section{The Authors}

Liliana Ballesteros Muñoz holds an M.A. in English Language Teaching for Self-directed Learning from Universidad de La Sabana (Colombia), a TESOL Diploma from Anaheim University (USA), a Specialist degree in Foreign Language Teaching and a BA in Spanish and English from Universidad Pedagógica, Colombia.

Silvana Tutistar Jojoa holds an M.A. in English Language Teaching for Self-directed Learning from Universidad de La Sabana (Colombia), a TESOL Diploma from Anaheim University (USA), a BA in Modern Languages and a Specialist degree in Translation Spanish-English from Universidad de Nariño, Colombia. 


\section{Appendix 1: Goal Setting Pre-Test}

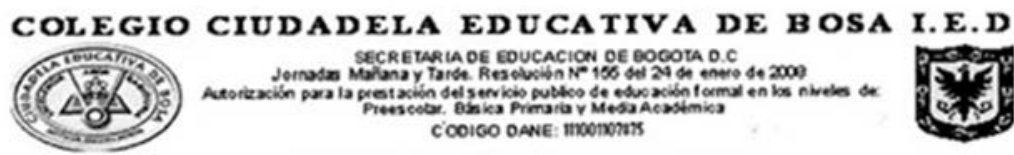

\section{Liliana Ballesteros M.}

The following test is designed to measure your ability to set goals. Please take a few moments to answer the goal setting questions below. This questionnaire is anonymous to encourage completely truthful answers!

\section{Directions:}

A. Select one of the following tasks:

1. Listen to the conversation.

2. Listen to the song.

3. Listen to the report.

B. After selecting a task, please answer the following questions:

Task:

1. What is your goal for this task?

2. How will you know that you have achieved that goal?

3. Do you have the skills to accomplish the goal?

4. How long do you think it will take you to achieve your goal?

5. What is the reason for accomplishing this goal? 


\section{Appendix 2: Sample Lesson Plan for Intervention}

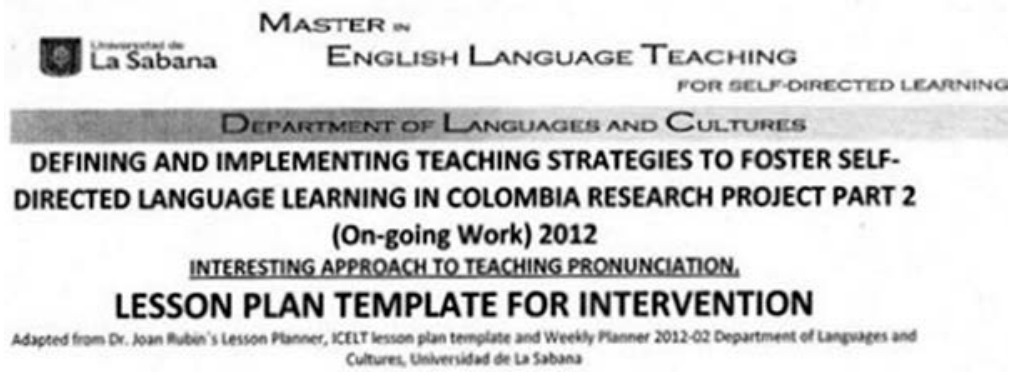

Name of co-researcher: Silvana Tutistar
University Code Number: 201113356

Institution: IED Miguel de Cervantes Saavedra

Date of Class: 03/09/2012

Week: No. 6

Time of Class: 6:40

Length of Class: 110 minutes

\begin{tabular}{|l|l}
\hline Class/grade: 9th & \\
\hline
\end{tabular}

Time Frame: 1 Class period

Room: 301

Number of students: 45

Number of years of English study: 5

Average age of students: $13-15$

Lesson Number

\begin{tabular}{|l|l|l|l|}
\hline 1 & 2 & 3 & 4 \\
\hline 5 & 6 & 7 & 8 \\
\hline
\end{tabular}

Level of students: A1 A2

Set Lesson Goals

The texts that will be used are narrative and descriptive.

\section{Language Goal}

Students will identify and discriminate specific sounds in a song /ei/, /au/, /or/.

Learning to Learn Goal

Students will identify specific details related to common sounds in English.
Assessment criteria

Students will recognize specific sounds in an oral text.

Assessment criteria

Students will classify new words according to the pronunciation.

Identify a topic for the lesson 


Materials and Resources
\begin{tabular}{|l|l|}
\hline Material: Handout & Annex 1: Silly Sentences \\
\hline Material: Song activity & Annex 2: "Stairway to Heaven" \\
\hline Material: Setting time-based goals & Annex 3: Checklist \\
\hline
\end{tabular}

\section{Assumed knowledge}

Students should know the pronunciation of some vowels in English.

\section{Anticipated problems and planned solutions}

Students might have problems with interference with the vowels in the mother tongue.

\section{Description of language items/skill(s)}

\begin{tabular}{|l|l|}
\hline Form & Present simple, present progressive \\
\hline Meaning & \\
\hline Use & Describe a situation \\
\hline Skill(s) and sub-skill(s) & Listening and speaking \\
\hline (For CLIL) Content Communication Cognition Culture & \\
\hline
\end{tabular}

\begin{tabular}{|c|c|c|c|c|c|}
\hline $\begin{array}{l}\text { Teacher's } \\
\text { role }\end{array}$ & Stage & Aim & $\begin{array}{c}\text { Procedure. } \\
\text { Teacher and student activity }\end{array}$ & Interaction & Time \\
\hline Facilitator & $\begin{array}{l}\text { Lead in } \\
\text { Preparation }\end{array}$ & $\begin{array}{l}\text { To make } \\
\text { students } \\
\text { interested in } \\
\text { the activities. }\end{array}$ & $\begin{array}{l}\text { Provide students with the handouts to } \\
\text { play with phonics (Annex 1). }\end{array}$ & $\begin{array}{l}\text { Teacher- } \\
\text { Student }\end{array}$ & $10 \mathrm{~min}$ \\
\hline Model & $\begin{array}{l}\text { Presentation } \\
\text { Modeling }\end{array}$ & $\begin{array}{l}\text { To help } \\
\text { students set } \\
\text { time-based } \\
\text { goals. }\end{array}$ & $\begin{array}{l}\text { Explain some rules of pronunciation } \\
\text { related to the following diphthongs: } \\
\text { /eI/, /au/, /ov/. Give examples. } \\
\text { Then explain how to set time-based } \\
\text { goals. Ask students to choose the } \\
\text { appropriate time-based goal and explain } \\
\text { why they consider it is appropriate. } \\
\text { Example: } \\
\text { By the end of the term I will identify at } \\
\text { least } 3 \text { more sounds in English. } \\
\text { I will differentiate the distinct sounds in } \\
\text { English. } \\
\text { By the end of the year I will learn how } \\
\text { to pronounce the different sounds in } \\
\text { English. }\end{array}$ & $\begin{array}{l}\text { Teacher- } \\
\text { Student }\end{array}$ & $20 \mathrm{~min}$ \\
\hline
\end{tabular}




\begin{tabular}{|c|c|c|c|c|c|}
\hline $\begin{array}{l}\text { Teacher's } \\
\text { role }\end{array}$ & Stage & Aim & $\begin{array}{l}\text { Procedure. } \\
\text { Teacher and student activity }\end{array}$ & Interaction & Time \\
\hline $\begin{array}{l}\text { Organizer } \\
\text { Participant }\end{array}$ & Practice & $\begin{array}{l}\text { To write } \\
\text { down } \\
\text { time-based } \\
\text { goals to a } \\
\text { specific task. }\end{array}$ & $\begin{array}{l}\text { Explain to students the task and ask } \\
\text { them to set a time-based goal to it. } \\
\text { TASK: Listen to the song and draw A } \\
\text { PICTURE OF what the song is about. } \\
\text { Play the song and ask students to } \\
\text { identify the sounds previously } \\
\text { introduced by the teacher (Annex 2). }\end{array}$ & $\begin{array}{l}\text { Student- } \\
\text { Student }\end{array}$ & $35 \mathrm{~min}$ \\
\hline Encourager & $\begin{array}{l}\text { Learner self- } \\
\text { evaluation }\end{array}$ & $\begin{array}{l}\text { To } \\
\text { self-evaluate } \\
\text { the setting } \\
\text { of goals. }\end{array}$ & $\begin{array}{l}\text { Ask students to assess their goal } \\
\text { achievement by using the checklist on } \\
\text { time-based goals. }\end{array}$ & Student & $15 \mathrm{~min}$ \\
\hline Prompter & $\begin{array}{l}\text { Problem } \\
\text { identification } \\
\text { / solution }\end{array}$ & & $\begin{array}{l}\text { In a plenary session students talk about } \\
\text { the problem(s) they had while working } \\
\text { on the task. Discuss the strategies they } \\
\text { can use when they have this kind of } \\
\text { difficulties. }\end{array}$ & $\begin{array}{l}\text { Teacher- } \\
\text { Student }\end{array}$ & \\
\hline \multirow[t]{2}{*}{ Encourager } & Wrap up & & $\begin{array}{l}\text { Ask students to write in their journals } \\
\text { their reflections about the task done in } \\
\text { the lesson by answering the questions } \\
\text { provided. }\end{array}$ & $\begin{array}{l}\text { Teacher- } \\
\text { Student }\end{array}$ & $15 \mathrm{~min}$ \\
\hline & $\begin{array}{l}\text { Expansion } \\
\text { /Independent } \\
\text { study }\end{array}$ & & $\begin{array}{l}\text { Ask students to listen to a song and } \\
\text { identify the sounds learned in class. } \\
\text { Then, invite them to write a } \\
\text { tongue-twister with words that contain } \\
\text { the sounds learned. }\end{array}$ & Students & $15 \mathrm{~min}$ \\
\hline
\end{tabular}




\section{Annex 1: Silly Sentences}

1. The following sentences are muddled up. Can you cut out the words and sort them out?

\begin{tabular}{||l|l|l|l|l|l|}
\hline flies & Kyle & kites & high. & very \\
\hline a game & in & We & played & May. \\
\hline are & around & town. & Clowns & the \\
toad & The & on the & jumps & Boat \\
\hline
\end{tabular}

2. Look at the pictures and read the clues. Then match the words to the pictures.

1) Water from the sky.
$---\ldots$ A dessert full of fruit.


Annex 2: Listen to the song and color the words with the /ai/ sound in yellow, words with the /er/ sound in blue, words with the /or/ sound in red, and with the /ar/ sound in green.

\section{Stairway to Heaven \\ (Led Zeppelin)}

There's a lady who's sure all that glitters is gold And she's buying a stairway to heaven.

When she gets there she knows, if the stores are all closed

With a word she can get what she came for.

Ooh, ooh, and she's buying a stairway to heaven.

There's a sign on the wall but she wants to be sure

'Cause you know sometimes words have two meanings.

In a tree by the brook, there's a songbird who sings,

Sometimes all of our thoughts are misgiven.

Ooh, it makes me wonder,

Ooh, it makes me wonder.

There's a feeling I get when I look to the west,

And my spirit is crying for leaving.

In my thoughts I have seen rings of smoke through the trees,

And the voices of those who stand looking.

Ooh, it makes me wonder,

Ooh, it really makes me wonder.

And it's whispered that soon, if we all call the tune,

Then the piper will lead us to reason.

And a new day will dawn for those who stand long,

And the forests will echo with laughter.

If there's a bustle in your hedgerow, don't be alarmed now,

It's just a spring clean for the May queen.

Yes, there are two paths you can go by, but in the long run

There's still time to change the road you're on.

And it makes me wonder.

Your head is humming and it won't go, in case you don't know,

The piper's calling you to join him, 
Dear lady, can you hear the wind blow, and did you know

Your stairway lies on the whispering wind?

And as we wind on down the road

Our shadows taller than our soul.

There walks a lady we all know

Who shines white light and wants to show

How everything still turns to gold.

And if you listen very hard

The tune will come to you at last.

When all are one and one is all

To be a rock and not to roll.

And she's buying a stairway to heaven.

Annex 3: Setting time-based goals checklist

The following checklist has been designed to help you assess if your goal IS time-based. Complete the chart with your own criteria.

Instruction: Check $(\checkmark)$ if the goal fulfills the requirements below.

\begin{tabular}{||l|l|l||}
\hline \multicolumn{1}{|c|}{ Items } & Yes & No \\
\hline - I have enough time to achieve the goal. & & \\
\hline - It will not take too much time to achieve the goal. & & \\
\hline - There is a limit of time to achieve my goal. & & \\
\hline$\cdot$ & & \\
\hline - & & \\
\hline
\end{tabular}




\section{Appendix 3: Self-Efficacy Pre- and Post-Test \\ COLEgIO CIUDADELA EDUCATIVA DE BOSA I.E.D

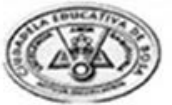 \\ SECRETARLA OE EOUCACION OE GOCOTA O.C \\ Jerrata Molonay Tarde. Reselueisn N 106 del 24 de enero 402000

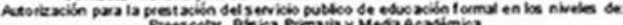

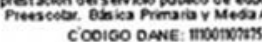

Directions: Read each sentence below. Then check $(\checkmark)$ the answer that best describes the degree of confidence you feel when listening to a song in English.

About songs

When listening to a song I have never heard:

\begin{tabular}{|c|c|c|c|}
\hline & $\begin{array}{l}\text { Highly certain } \\
\text { can do }\end{array}$ & $\begin{array}{l}\text { Moderately } \\
\text { can do }\end{array}$ & $\begin{array}{l}\text { Cannot } \\
\text { do at all }\end{array}$ \\
\hline $\begin{array}{l}\text { 1. I can make predictions about what } \\
\text { the song is going to be about based } \\
\text { on the title. }\end{array}$ & & & \\
\hline $\begin{array}{l}\text { 2. I can plan the strategy I am going to } \\
\text { use to do the listening proposed by } \\
\text { the teacher. }\end{array}$ & & & \\
\hline $\begin{array}{l}\text { 3. I can compare the new song with similar } \\
\text { ones I have heard before. }\end{array}$ & & & \\
\hline $\begin{array}{l}\text { 4. I can tell what kind of song it is: a love } \\
\text { song, a patriotic song, a description of a } \\
\text { feeling. }\end{array}$ & & & \\
\hline $\begin{array}{l}\text { 5. I can tell my friends about the } \\
\text { sentiment. }\end{array}$ & & & \\
\hline $\begin{array}{l}\text { 6. I can guess the meaning of unknown } \\
\text { words by linking them to words I } \\
\text { already know. }\end{array}$ & & & \\
\hline $\begin{array}{l}\text { 7. I can remember some of the words I } \\
\text { have listened to. }\end{array}$ & & & \\
\hline 8. I can identify words similar to Spanish. & & & \\
\hline $\begin{array}{l}\text { 9. I can use my knowledge to help me } \\
\text { guess the words I did not understand. }\end{array}$ & & & \\
\hline
\end{tabular}




\begin{tabular}{||l|l|l|l||}
\hline & $\begin{array}{c}\text { Highly certain } \\
\text { can do }\end{array}$ & $\begin{array}{c}\text { Moderately } \\
\text { can do }\end{array}$ & $\begin{array}{c}\text { Cannot } \\
\text { do at all }\end{array}$ \\
\hline 10. I can translate key words. & & & \\
\hline $\begin{array}{l}\text { 11. I can identify the genre of song (pop, } \\
\text { rock, ballad, rap, etc.). }\end{array}$ & & & \\
\hline $\begin{array}{l}\text { 12. I can think of a solution if I have a } \\
\text { problem understanding the song. }\end{array}$ & & & \\
\hline 13. I can ask my teacher for help if I need it. & & & \\
\hline $\begin{array}{l}\text { 14. I can reflect about how I listened and } \\
\text { about what I might do differently next } \\
\text { time. }\end{array}$ & & & \\
\hline $\begin{array}{l}\text { 15. I can explain in my own words what the } \\
\text { song is about. }\end{array}$ & & & \\
\hline $\begin{array}{l}\text { 16. I can give an opinion about what I have } \\
\text { listened to. }\end{array}$ & & & \\
\hline \hline
\end{tabular}




\section{Appendix 4: Journals}

Excerpts from students' reflections after having started the intervention. ${ }^{1}$

In this class, we continue setting goals, today we work on attainable goals, we gave some examples and share with our partners the goals we had writte. We check if the goals were well design. After that, the teacher made us work on the song "I Won't Give Up," we draw about what we felt when we listen to the song, it was difficult because the first time I listened to the song I only understood two o three words, then the teacher gave us the lirycs of the song and it was easier. I felt a little dissapointed because I discovered lack of vocabulary however I asked for my partner's help, to finish the activity, so I guess that I didn't fully accomplish the goal that was to understand and sing the chorus at least. (S2, Seventh Grade)

Today the teacher talked about a special work we are going to develop with her about her master studies, she asked us willingness since there will be 10 sessions, I'm not sure what is going to be about, however the teacher told us it was related to songs; I hope it is rock because I like it very much.

After that, she talked about self.directed learning; I have never heard about this she said it is useful specially in education and it can help us in the future when we join the university, it seems interesting but complicated, Later on, we worked on some matching exercises and she read the fable "The Crow and the Pitcher" it was easy because it had some drawings, that was the thing I liked the most, what I didn't like is that we could not listen to the song. (S9, Ninth Grade)

1 The original journals were written in Spanish. 